\title{
Stainless Steel Bracket with Fluoridated Dentifrices - Comparative Clinical and Microbiological study
}

\author{
Dr. Aseem Sharma ${ }^{1}$, Dr Sachin Upadhyay ${ }^{2 *}$, Dr. Gaurav Didhra ${ }^{3}$, Dr. Mandeep Nain ${ }^{4}$, Dr. Yatharth Goel ${ }^{5}$, Dr. Neelam \\ Chauhan $^{6}$ \\ ${ }^{1}$ Senior Lecturer in Department of Orthodontics and Dentofacial Orthopedics at Himachal Institute of Dental Sciences Paonta Sahib, Himachal Pradesh \\ India \\ ${ }^{2}$ Senior Lecturer in Department of Orthodontics and Dentofacial Orthopedics at Himachal Institute of Dental Sciences Paonta Sahib, Himachal Pradesh \\ India \\ ${ }^{3}$ Director at Dent-O-Care, Opp UCO Bank Main bazaar, Mehatpur, Una India \\ ${ }^{4}$ Post Graduate Student in the Department of Prosthodontics, DAV Dental College, Yamuna Nagar Haryana India \\ ${ }^{5}$ Director at Dantam Dental Solutions 44, Civil lines, Jadugar Road, Roorkee (U.K) India \\ ${ }^{6}$ Consultant Orthodontist at Kullu Smiles, Kullu Himachal Pradesh India
}

DOI: 10.36348/sjodr.2019.v04i09.014

| Received: 11.09.2019| Accepted: 20.09.2019| Published: 30.09.2019

*Corresponding author: Dr. Sachin Upadhyay

\section{Abstract}

Background: To ascertain if fluoridated dentifrices have an effect on Streptococcus mutans count in orthodontic patients with Stainless steel brackets. Material and method: patient had tooth No's 12 included in the study with Stainless steel bracket bonded. Dentifrices tested were Fluoride based. Conventional tooth paste was considered as control group. Result: Paired T test compared the means of Streptococcus mutans count around Stainless steel bracket at different time intervals. Conclusion: This shows Stainless steel bracket has statistically significant reduction of Streptococcus mutans with Fluoride toothpaste.

Keywords: Stainless steel bracket, Fluoride, Streptococcus Mutans.

Copyright @ 2019: This is an open-access article distributed under the terms of the Creative Commons Attribution license which permits unrestricted use, distribution, and reproduction in any medium for non-commercial use (NonCommercial, or CC-BY-NC) provided the original author and source are credited.

\section{INTRODUCTION}

The most common Colgate contains Fluoride. Fluoride acts primarily via topical mechanisms and brings about inhibition of demineralization enhancement of remineralization at the crystal structure and inhibition of bacterial enzyme. Marsh and Bradshaw [1] found that 19 ppm of fluoride in an in vitro mixed culture study inhibited the growth of Streptococcus mutans. As bacteria in dental plaque is one of the main factors causing periodontal inflammation; careful plaque control is very important. The extrinsic variables affecting the bacterial count (besides the confounding intrinsic host factors) may be considered to be the type of tooth brush used by the patient and the method of brushing, the effect of the dentifrice used and the quality and quantity of orthodontic attachments in the oral cavity. Streptococcus mutans is a potent initiator of caries because there are a variety of virulence factors unique to the bacterium and play an important role in caries initiation. Firstly, Streptococcus mutans is an anaerobic bacterium known to produce lactic acid as part of its metabolism. Secondly, there is the ability of Streptococcus mutans to bind to tooth surfaces in the presence of sucrose by the formation of water-insoluble glucans, a polysaccharide that aids in binding the bacterium to the tooth [1].The most important virulence factor is the acidophilcity of Streptococcus mutans. Unlike the majority of oral microorganisms, Streptococcus mutans thrives under acidic conditions and becomes the dominant bacterium in cultures with permanently reduced $\mathrm{pH}$ [2]. Though, brushing teeth twice a day is considered reasonably effective in plaque and bacterial count reduction, the common prevalence of gingival inflammation in orthodontic patients often suggests inadequate oral hygiene procedures in most patients. The household name for toothpaste is often synonymous with "Colgate" in rural India to designate a dentifrice. Juvvadi[2] found a high Fluoride concentration in the oral cavity might inhibit acid production by bacteria 
and may reduce the number Streptococcus mutans. Hence, this study of microbiological assay of Streptococcus mutans with an objective to study the performance and measure the efficacy of Fluoride toothpastes- Fluoride based herbal toothpaste with Stainless steel Bracket is done.

\section{AIM AND OBJECTIVES}

To ascertain if Fluoride dentifrices have an effect on Streptococcus mutans count in orthodontic patients with Stainless steel Brackets

\section{MATERIAL AND METHOD}

\section{Nature of Study}

Randomized, prospective, cross sectional single blinded microbiological assay study with each patient acting his /her own control in this study.

\section{Area of Study}

Department of Orthodontics and Dentofacial Orthopedics, Divya Jyoti College of Dental Sciences and Research and Microbiological Assay were conducted in Divya Jyoti Hospital.

\section{Ethical Clearance}

This study was approved by Institutional Committee (IEC No DJD/IEC/2014/A-001). A written consent was taken from each participating subject.

\section{Inclusion criteria}

- Patient with similar socioeconomic strata \& common food habits.

- Patients free of oral/parental antibiotics for one month.

- No periodontal \& systemic disorders

- Patients with no crowding and who have had alignment and leveling completed.

\begin{tabular}{|c|c|l|}
\multicolumn{4}{c}{ Dentifrices } \\
\hline CODES & COLOR & \multicolumn{1}{c|}{ DENTIFRICES } \\
\hline $\mathbf{X}$ & White & $\begin{array}{l}\text { Fluoride BasedToothpaste } \\
\text { (Colgate Palmolive) }\end{array}$ \\
\hline
\end{tabular}

\begin{tabular}{|c|l|}
\multicolumn{1}{c}{ Bracket Type } \\
\hline S. No & \multicolumn{1}{c|}{ Bracket type } \\
\hline $\mathbf{1}$ & $\begin{array}{l}\text { Passive Stainless steel Bracket } \\
\text { [ Empower 0.22 MBT American } \\
\text { Orthodontics] }\end{array}$ \\
\hline
\end{tabular}

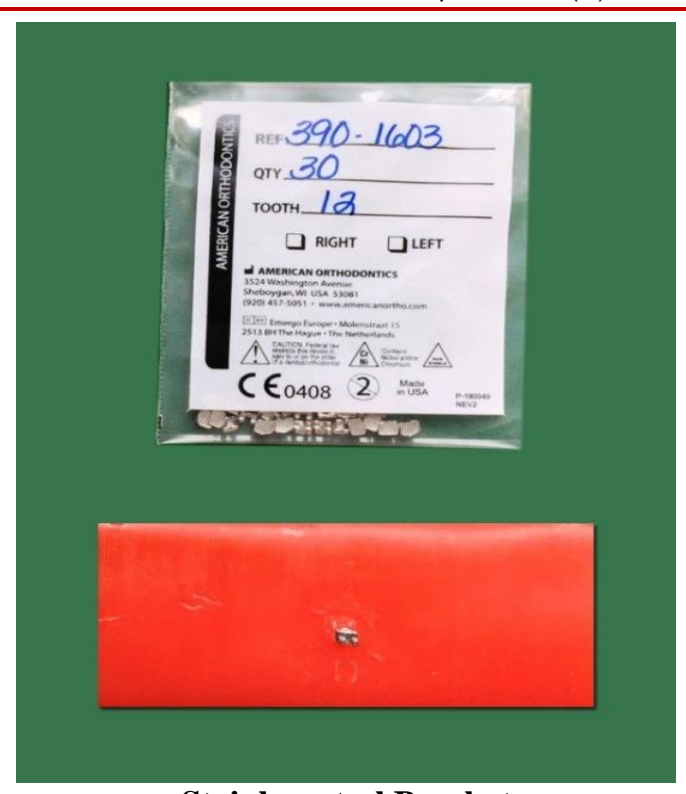

\section{Stainless steel Bracket}

\section{Steps and Time Interval of Study}

- Each group consists of 30 teeth with 30 brackets to be tested.

- Each patient served as his/her own control as 1 types of bracket were tested in the same mouth at the same time period.

- Each patient had tooth No's 12 included in the study with ceramic bracket bonded.

- Dentifrices tested were Fluoride based.

- The dentifrices were dispensed into $5 \mathrm{ml}$ bottles coded as $\mathbf{X}$ for Fluoride toothpaste -. Color Coding of Dentifrices

- Conventional tooth paste was considered as control group.

\begin{tabular}{|c|c|c|c|}
\hline S. No & N & Type & $\begin{array}{c}\text { Bracket Bonded on } \\
\text { Tooth Number }\end{array}$ \\
\hline I & 30 & $\begin{array}{c}\text { Stainless Steel } \\
\text { Rhomboidal MBT }\end{array}$ & 12 \\
\hline
\end{tabular}

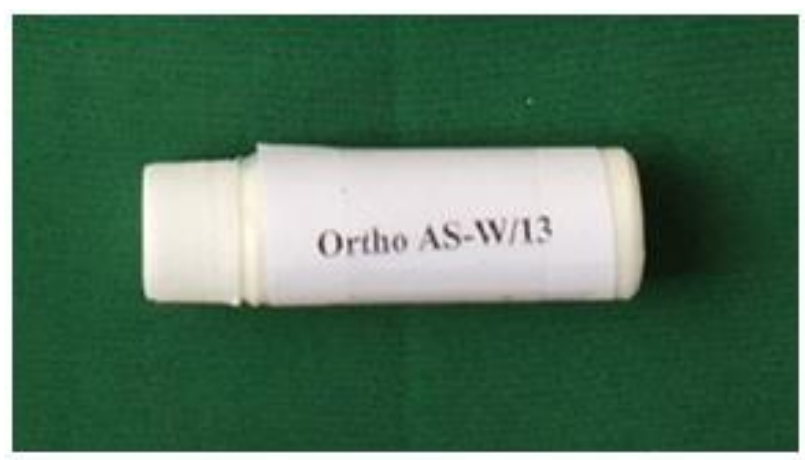

\begin{tabular}{|c|c|c|}
\hline CODES & COLOR & \multicolumn{1}{c|}{ DENTIFRICES } \\
$\mathbf{X}$ & White & $\begin{array}{l}\text { Fluoride Dentifrice } \\
\text { (Colgate Palmolive) containing } \\
\text { fluoride. }\end{array}$ \\
\hline
\end{tabular}




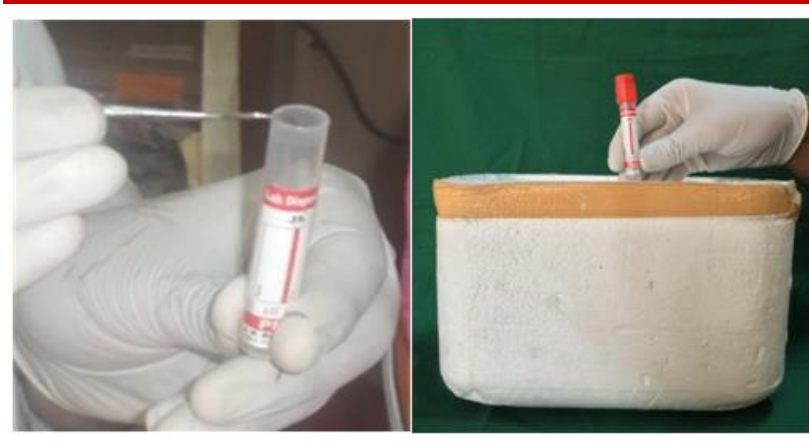

Ice Box Plaque Collection and Transportation

Plaque collection and transportation

- Plaque sample placed in $5 \mathrm{ml}$ sterilized vials with1 $\mathrm{ml}$ distill water.

- Sterilized vials were transported in icebox to the lab.

- The bacteriological study was conducted by Dilution Plating Method.

- The growth media used was Mutans-Sanguis Agar.

\section{Oral Hygiene Instructions}

- The subjects were given oral hygiene instructions \& requested to refrain from using any other oral hygiene products like mouthwash etc.

- The subjects were instructed to follow standard oral hygiene regime which included brushing twice a day with toothpaste as prescribed in the study regime.

- The patients were advised to rinse thoroughly after every meal.

Table Shows: Time Interval of Tooth Paste Usage

\begin{tabular}{|l|l|}
\hline TOOTHPASTE & $\begin{array}{l}\text { TIME } \\
\text { INTERVAL }\end{array}$ \\
\hline $\begin{array}{l}\text { Baseline without use of study } \\
\text { Dentifrices }\end{array}$ & $1^{\text {st }}$ to $2^{\text {nd }}$ Day \\
\hline Fluoride $(\mathrm{X})$ & $3^{\text {rd }}$ to 8 th Day \\
\hline
\end{tabular}

Table Shows: Time Interval of Plaque Collection

\begin{tabular}{|c|c|c|}
\hline Sample Count & $\begin{array}{c}\text { Time } \\
\text { Interval }\end{array}$ & $\begin{array}{c}\text { Day } \\
\text { Count }\end{array}$ \\
\hline $\begin{array}{c}\text { Sample No.1 } \\
\text { (baseline without use of } \\
\text { study dentifrices) }\end{array}$ & $\begin{array}{c}\left(\mathbf{T}_{\mathbf{1}}\right) \\
\text { (Start of } \\
\text { study })\end{array}$ & Day: $\mathbf{1}$ \\
\hline Sample No.2 & $\mathbf{T}_{\mathbf{2}}$ & Day : $\mathbf{3}$ \\
\hline Sample No.3 & $\mathbf{T}_{\mathbf{3}}$ & Day : $\mathbf{8}$ \\
\hline
\end{tabular}

\section{Plaque Collection Method}

- Patients were requested to refrain from eating or drinking 1 hour prior to sample collection.

- Plaque sample was collected by Four Pass Technique at midmorning (11 a.m.).
- In this technique the explorer tip is moved around the circumference of the bracket at the bracket tooth interface.

- Four passes, along the tooth at the bracket interface at the gingival, mesial, distal, and occlusal aspects are done to avoid overloading the instrument tip.

- This is considered an effective method of obtaining the total plaque .Plaque samples were placed in sterilized vials having distilled water in it.

\section{Laboratory Equipment's}

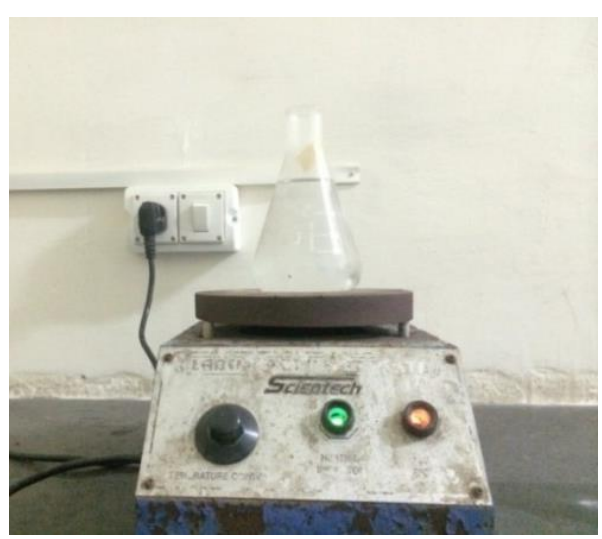

Hot Plate

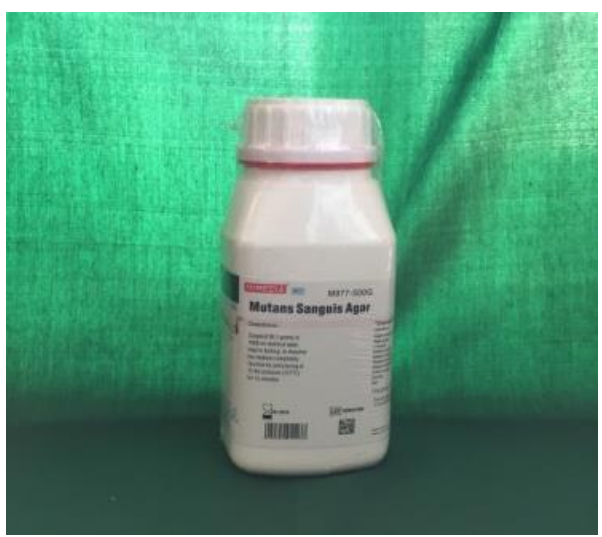

Mutans Sanguis Agar

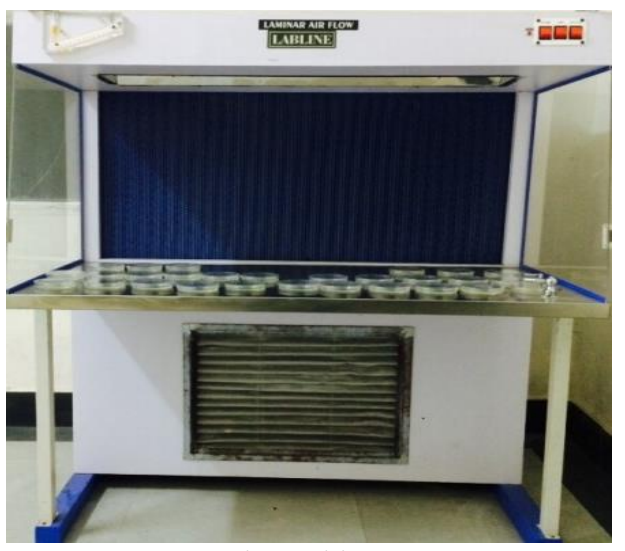

Laminar Air Flow 
Aseem Sharma et al; Saudi J Oral Dent Res, Sep 2019; 4(9): 642-647

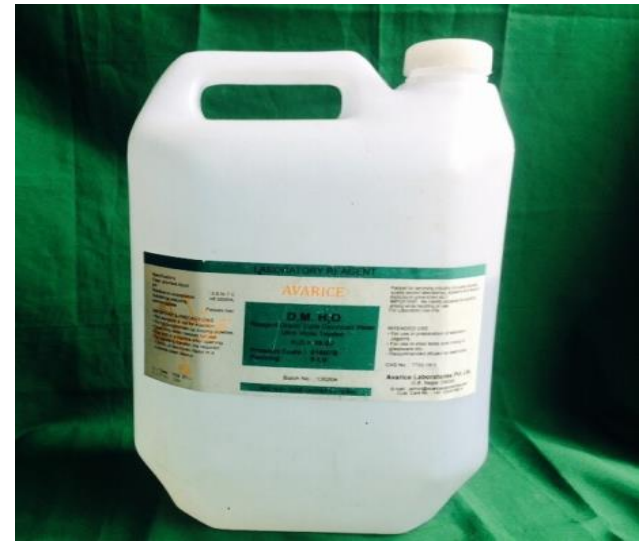

Distilled Water

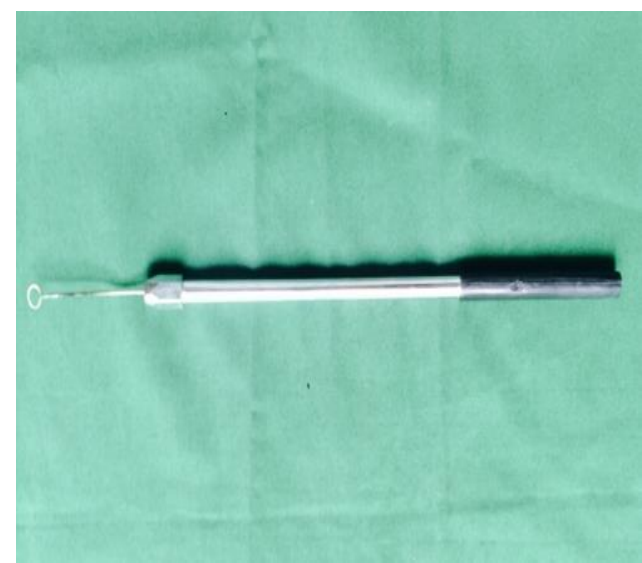

Wire Loop

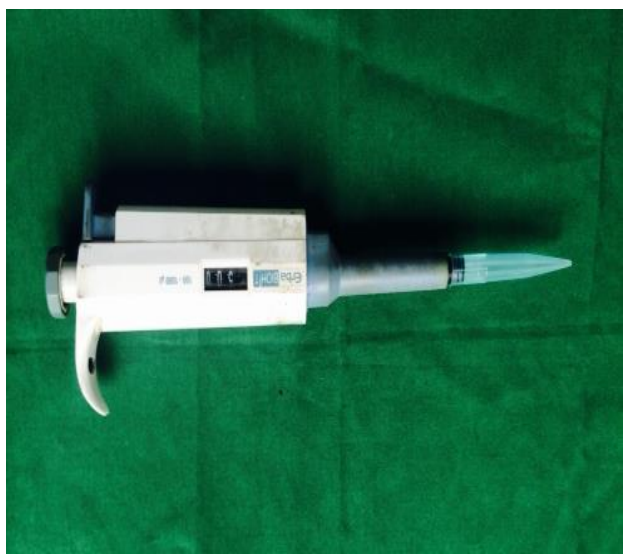

Micropipette

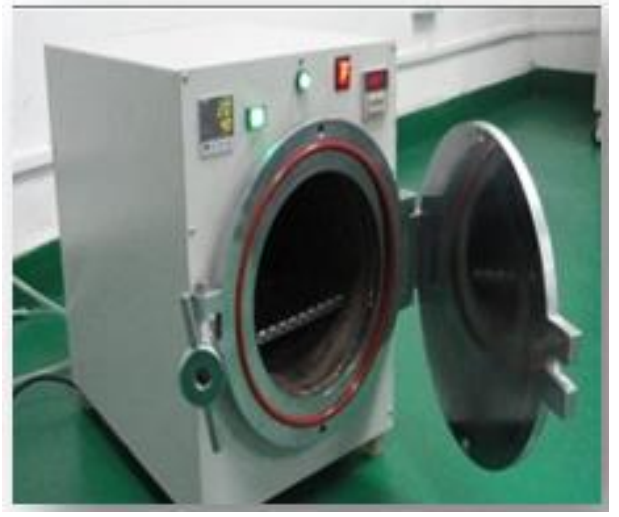

Sterilization of Diluted Agar Medium in Autoclave

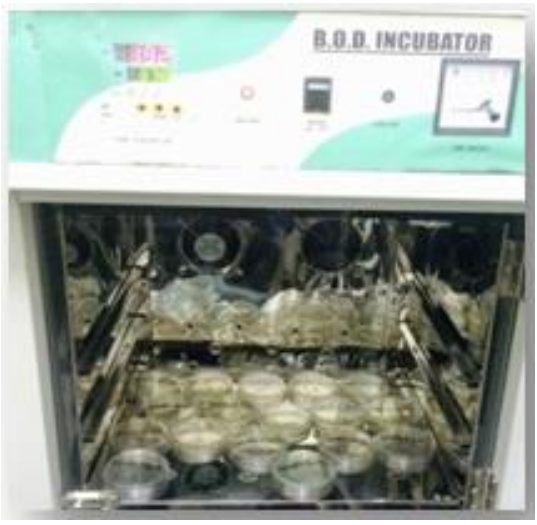

Petridishes Placed Inside Incubator

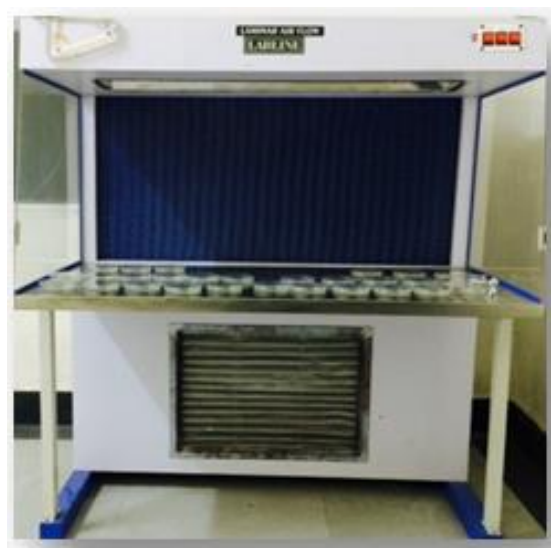

Solidification of Agar Medium in Laminar Air Flow

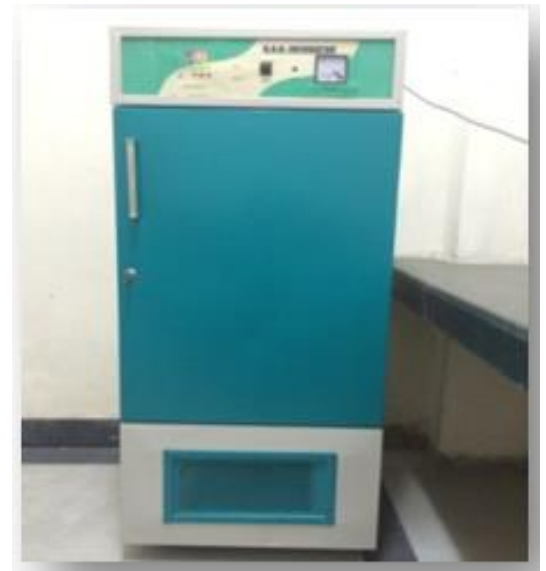

Incubator

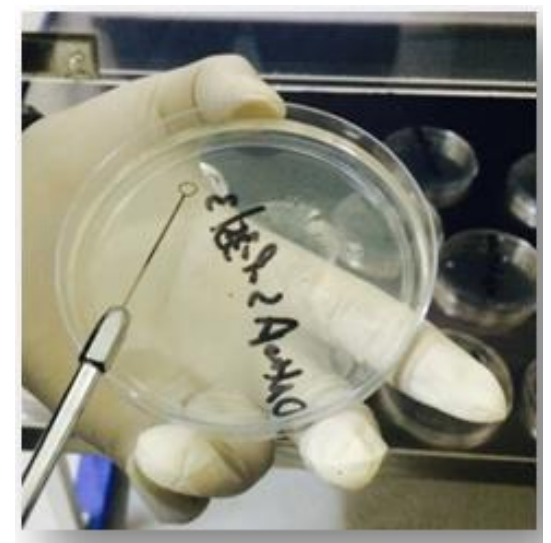

Spreading of Plaque Sample over Petridish

(c) 2019 |Published by Scholars Middle East Publishers, Dubai, United Arab Emirates 


\begin{tabular}{|c|l|}
\hline S.No & Item \\
\hline $\mathbf{1}$ & Autoclave \\
\hline $\mathbf{2}$ & Hotplate \\
\hline $\mathbf{3}$ & Petridish \\
\hline $\mathbf{4}$ & Micropipette \\
\hline $\mathbf{5}$ & Laminar flow Cabinet \\
\hline $\mathbf{6}$ & Conical flask \\
\hline $\mathbf{7}$ & Cotton Plug \\
\hline $\mathbf{8}$ & Sterilized Wire loop \\
\hline $\mathbf{9}$ & Incubator \\
\hline $\mathbf{1 0}$ & Disposable gloves \\
\hline $\mathbf{1 1}$ & U shape flask \\
\hline $\mathbf{1 2}$ & Disposable Mouth mask \\
\hline
\end{tabular}

\section{RESULT}

Table Shows: Comparison of Means of Streptococcus mutans Count at Different Time Intervals around Stainless steel Bracket by Paired T - Test

\begin{tabular}{|l|l|l|c|c|c|c|}
\hline \multicolumn{3}{|c|}{ Days } & $\begin{array}{c}\text { Mean } \\
\text { difference }\end{array}$ & T & d.f. & P value \\
\hline $\begin{array}{l}\text { Day } \\
\text { 1 }\end{array}$ & - & $\begin{array}{l}\text { Day } \\
\mathbf{3}\end{array}$ & 0.16667 & 1.153 & 29 & $0.258^{*}$ \\
\hline $\begin{array}{l}\text { Day } \\
\text { 3 }\end{array}$ & - & $\begin{array}{l}\text { Day } \\
\mathbf{8}\end{array}$ & 0.66667 & 3.808 & 29 & $0.001 * * *$ \\
\hline
\end{tabular}
0.05, Not Significant $\mathrm{p}>0.05$

- $\quad$ Paired T test compared the means of Streptococcus mutans count around Stainless steel bracket at different time intervals.

- Difference between Day 3 \& Day 8 with Fluoride dentifrice was highly significant statistically

- Difference between Day 1 \& Day 3 was not statistically significant.

- The mean difference between Day 3 \& Day 8 is 0.001 .

\section{CONCLUSION}

- This shows Stainless steel bracket has statistically significant reduction of Streptococcus mutans with Fluoride toothpaste.

\section{DISCUSSION}

The increased time and difficulty of maintaining good oral hygiene during orthodontic treatment are challenges faced by patients and the levels of oral bacteria have been reported to increase five folds due to the orthodontic devices and attachments [1]. Emilson CG. Stated that most orthodontic patients are not able to perform effective plaque control, and therefore develop mild to moderate gingivitis during treatment with fixed appliances. Microorganisms play a major role in causation of WSL and dental caries. Entire removal of microorganism from the oral cavity is difficult but their count can be reduced with the help of various preventive measures so that it becomes less cariogenic. The market is flooded with numerous bracket types of different biomaterials. Literature evidences that adherence of plaque to the fixed appliance is largely contributed by the bracket material [2] as it could play a role in the degree of bacterial adhesion and plaque accumulation as well as in the risk of development of WSL. The initial affinity of bacteria to solid surfaces is due mostly to electrostatic and hydrophobic interactions. Surfaces with high surface free energy more easily attract bacteria such as S. mutans [3]. Currently Brackets are being driven by manufacturers as having a hygiene advantage, while many studies have reported in the contrary [5]. The results of the current research study showed significant reduction around Stainless steel bracket with Fluoride toothpaste. The value of current study suggests that fluoridated dentifrices have good antimicrobial effects on caries producing bacteria, thus can be used in orthodontic patients and as a regular home care preventive aid in combating dental caries. Simultaneously, the world of cleansing agents has also widened and a fresh interest in 'organic plant based products is on the rise as alternative medicine is widely propagated and practiced.

\section{REFERENCES}

1. Bradshaw, D. J., McKee, A. S., \& Marsh, P. D. (1990). Prevention of population shifts in oral microbial communities in vitro by low fluoride concentrations. Journal of dental research, 69(2), 436-441.

2. Rammohan, S. N., Juvvadi, S. R., Gandikota, C. S., Challa, P., Manne, R., \& Mathur, A. (2012). Adherence of Streptococcus mutans and Candida albicans to different bracket materials. Journal of pharmacy \& bioallied sciences, 4(Suppl 2), S212.

3. Ohsumi, T., Takenaka, S., Wakamatsu, R., Sakaue, Y., Narisawa, N., Senpuku, H., \& Okiji, T. (2015). Residual structure of Streptococcus mutans biofilm following complete disinfection favors secondary bacterial adhesion and biofilm redevelopment. PloS one, 10(1), e0116647.

4. Pujari, S. (2015). Bacteria Present In a Sample by Serial Dilution Agar Plating Method or Total Plate Count (TPC). Int J Microbiology, 6(2):101-103.

5. Little, W. A., Korts, D. C., Thomson, L. A., \& Bowen, W. H. (1977). Comparative recovery of Streptococcus mutans on ten isolation media. Journal of clinical microbiology, 5(6), 578-583.

6. Hoover, C. I., \& Newbrun, E. (1977). Survival of bacteria from human dental plaque under various transport conditions. Journal of clinical microbiology, 6(3), 212-218. 
Aseem Sharma et al; Saudi J Oral Dent Res, Sep 2019; 4(9): 642-647

7. Duchin, S., \& Van Houte, J. (1978). Colonization of teeth in humans by Streptococcus mutans as related to its concentration in saliva and host age. Infection and immunity, 20(1), 120-125.

8. EMILSON, C. G. (1983). Prevalence of Streptococcus mutans with different colonial morphologies in human plaque and saliva. European Journal of Oral Sciences, 91(1), 26-32.
9. Wan, A. K. L., Seow, W. K., Walsh, L. J., \& Bird, P. S. (2002). Comparison of five selective media for the growth and enumeration of Streptococcus mutans. Australian dental journal,47(1), 21-26.

10. Yuwono, C. L., Soegiharto, B. M., \& Jazaldi, F. (2013). Effectiveness of herbal and non-herbal toothpastes in reducing dental plaque accumulation. Journal of Dentistry Indonesia, 19(3), 70-74. 